\title{
HTLV-1 Tax disrupts the host epigenome by interacting with a Polycomb group protein EZH2
}

\author{
Dai Fujikawa', Makoto Yamagishi', Naoya Kurokawa', Ai Soejima', Takaomi Ishida², Yuetsu Tanaka ${ }^{3}$ \\ Kazumi Nakano', Toshiki Watanabe ${ }^{1 *}$ \\ From 16th International Conference on Human Retroviruses: HTLV and Related Viruses \\ Montreal, Canada. 26-30 June 2013
}

ATL is a highly aggressive T-cell neoplasm caused by HTLV-1. We have recently demonstrated that EZH2, a catalytic enzyme of histone H3K27 methylation, is overexpressed in ATL cells, which contributes to persistent NF- $\kappa \mathrm{B}$ activation by repressing a tumor-suppressive miRNA, miR-31. This suggests that epigenetic abnormalities are closely associated with the molecular hallmarks of leukemic cells. However, the mechanisms by which epigenetic disruption is caused and sustained in HTLV-1 infected cells remain to be clarified. In the present study, we first found that Tax directly interacts with EZH2 in HTLV-1 infected cells. Given that epigenetic state is directly affected by cell lineage-dependent transcription factors and genetic background, we assessed the functional interconnection between HTLV-1 Tax and the histone methyltransferases in an appropriate model. Using a lentivirus vector, we introduced $\operatorname{tax}$ gene into peripheral blood mononuclear cells (PBMCs) and CD4+ T-cells from healthy donors and established Tax-transduced T-cells. In this model, we observed overexpression of EZH2, aberrant accumulation of H3K27 trimethylation, and epigenetic silencing of $p 21^{\text {cip1/wafl }}$, all of which have been observed in primary ATL cells. In addition, EZH2 inhibition reduced the viability of Tax-transduced T-cells. Our results strongly suggest that Tax epigenetically affects gene expression through its interaction with $\mathrm{EZH} 2$, and that Tax-dependent epigenetic abnormalities may be involved in determining the molecular characteristics of HTLV-1-infected cells as well as ATL cells. Since epigenetic marks are potentially reversible, development of genuine epigenetic-targeted drugs will hold great promise in treatment of HTLV-1-related diseases.

* Correspondence: tnabe@ims.u-tokyo.ac.jp

'Graduate School of Frontier Sciences, The University of Tokyo, Tokyo, Japan Full list of author information is available at the end of the article

\section{Authors' details}

'Graduate School of Frontier Sciences, The University of Tokyo, Tokyo, Japan. ${ }^{2}$ Institute of Medical Science, The University of Tokyo, Tokyo, Japan.

${ }^{3}$ Graduate School and Faculty of Medicine, University of the Ryukyus, Okinawa, Japan.

Published: 7 January 2014

doi:10.1186/1742-4690-11-S1-P144

Cite this article as: Fujikawa et al:: HTLV-1 Tax disrupts the host epigenome by interacting with a Polycomb group protein EZH2. Retrovirology 2014 11(Suppl 1):P144.
Submit your next manuscript to BioMed Central and take full advantage of:

- Convenient online submission

- Thorough peer review

- No space constraints or color figure charges

- Immediate publication on acceptance

- Inclusion in PubMed, CAS, Scopus and Google Scholar

- Research which is freely available for redistribution

Submit your manuscript at www.biomedcentral.com/submit
() Biomed Central 